\title{
高空間分解スキャニングライダー：トンネル内壁面の精密調査に向けて
}

村上 武晴，斎藤 徳人，道川 隆士，小町祐一，岡村幸太郎，坂下 亨男，

木暮 繁，加瀬 究，和田 智之，緑川 克美

理化学研究所 光量子工学研究領域 ( ₹351-0198 埼玉県和光市広沢2-1)

\section{High-Spatial-Resolution Scanning LIDAR: Towards Accurate Inspection of Tunnel Inner Wall}

\author{
Takeharu MURAKAMI, Norihito SAITO, Takashi MICHIKAWA, Yuichi KOMACHI, \\ Kotaro OKAMURA, Michio SAKASHITA, Shigeru KOGURE, \\ Kiwamu KASE, Satoshi WADA, and Katsumi MIDORIKAWA \\ RIKEN Center for Advanced Photonics, 2-1 Hirosawa, Wako, Saitama 351-0198
}

(Received April 10, 2017)

\begin{abstract}
This article introduces a remote laser inspection system that detects cracks on the concrete wall of tunnels. The system consists of three features: distance measurement using an interferometer equipped with a frequency-shifted feedback (FSF) laser, high-speed and high-resolution imaging using a reflected light imaging system, and spectroscopic imaging using triple lasers with different wavelengths. The features have potential to replace conventional manual-based inspection tasks.
\end{abstract}

Key Words: LIDAR, Infrastructure, FSF laser

1. はじめに

高度経済成長期に建設されたトンネルは，耐用年数が 近づき，劣化が進んでいる。トンネル壁を形成してい る覆工コンクリートは，山から圧縮応力を受けている場 合と，単なる覆いとしての役割を担っている場合がある が, 基本的に, その構造は安定しており, トンネルが崩 落することはない。一方，コンクリートの剥離につなが る劣化は，小規模であっても，通行車両や歩行者に大き な危害を及ぼす恐れがある。例えば，1999年に新幹線卜 ンネルにおいて，重量200 kgのコンクリート片が剥落す るという事故が発生した1)。幸い人的な被害はなかった ものの，老朽化したインフラの危険性が明らかになった 一例であると言える。

このようなコンクリートの剥落による事故を未然に防 ぐため，平成26年に改定された道路法施工規則によっ て, 全ての道路及び鉄道トンネルの点検を定期的に行 い，危険と判断された箇所には補修を施すことが定めら れた。定期点検においては，トンネル内壁を形成する覆 エコンクリートのうき, 剥離の有無及び範囲を高い精度 で見極めることと，それらを除去することに主眼が置か れている，特に，ひび割れが剥落の兆候として重要な観 察対象とされている。幅 $0.2 \mathrm{~mm}$ 以上のすべてのひび割 れを観察対象とし, その幅, 長さ, 形状などが重要な判 断材料になる。
現在，検査会社が実施しているトンネルの定期点検の 代表的な方法は，近接目視，打音検査，触診である。作 業者は，触診できる距離まで近づき，目視でひび割れ等 を確認するとともに，手持ちのハンマーで壁面を叨いて 空洞の有無を確認する。剥落する危険がある箇所は，八 ンマーにより除去する。この目視による検査は, 詳細な 情報が得られるだけでなく，危険箇所を一連の作業で除 去できる利点がある。その一方で，効率性と客観性に関 して問題点がある。天井に近い壁面の近接目視が高所作 業車上での作業となるため, 点検効率は限定されたもの となるだけでなく，交通規制が必要となるなど，膨大な コストが必要となる。また，ひび割れの記述は現場で手 書きにより行われることが多い，その結果，点検記録の 情報化に膨大な工数を必要となるだけでなく，正確にひ び割れを記述できない場合がある。

そのような状況の中, 人手による労力とメンテナンス 作業量の削減を目指した様々なインフラ施設の維持管理 技術が提案されている2,3)。表面から視認できない内部 欠陷を対象にした研究 ${ }^{4-7)} も$ 行われているものの，初期 段階の欠陥を検出することは難しい。一方, 内部欠陥の 予兆はトンネル表面にひび割れとして現れることが多 い. 本研究ではこのひび割れを遠隔で計測する問題に着 目した

ひび割れ検出については，国が定めた幅 $0.2 \mathrm{~mm}$ 以上 のひび割れを全て検出でき，遠隔かつ高速な計測技術が 
求められている。この要求に対して取りうるアプローチ は，デジタルカメラを用いた方法，レーザーを用いた方 法の2つに大きく分けられる。

デジタルカメラを用いる方法は，撮影した画像に対し て，画像処理を適用することでコンクリート構造物上に あるひび割れ等の劣化情報を検出し，記録する方法であ る ${ }^{8,9)}$ 、ひび割れ箇所の輝度は通常の壁面と比較すると 低いことが多いので，エッジ検出 ${ }^{10)}$ などを用いることに より，ひび割れを検出する，また，機械学習と組み合わ せることで検出率を向上させる試みも行われている ${ }^{8,11}$

また，車載した複数のカメラで走行中に撮影した写真 をつなぎ合わせることで, トンネル全面の壁面情報を車 両の走行速度で一度に取得できる。しかし, 走行中に撮 影車載カメラによる高い分解能でのデータ取得は難しい という問題がある。実際に既往の研究では, $1 \mathrm{~mm}$ より も細かいひび割れは議論の対象になっていない場合が多 い.

デジタルカメラを使用する方法の限界点に，トンネル 表面の変色により，ひび割れを検出できない点がある.

Fig. 1 に水漏れや石灰, 排気ガスによってトンネル表面 が変色したため，ひび割れの認識が難しい例を示す。こ れは，ひび割れの本質的な特徵が幾何学的なものである にも関わらず，画像には光の反射率が記録されているこ とによる，実際にこれらのケースでは検出の誤り率が高 いことが報告されており ${ }^{12,13)}$ ，写真画像によるひび割れ の検出の限界を示している.

レーザーを用いた方法は，レンズによって様々な直径 のスポットに成形できるレーザー光の特性を利用した計 測方法である。レーザー光は，空気中を長距離にわたっ て伝播できるため，遠隔計測によく利用されている．

インフラ構造物を対象としたレーザー測定に関する研 究は, さらに2種類に分けられる。一つは, レーザー光 を単一スポット光に集光し, 高速に振り回すことで大面 積の画像を取得し，ひび割れ検出に利用する方法であ $ろ^{14)}$. 単一の計測器により, データの合成処理なしに連 続したトンネル全面の画像が得られるというメリットを

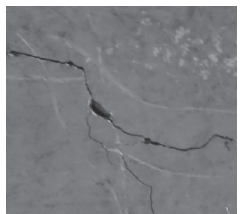

(a)

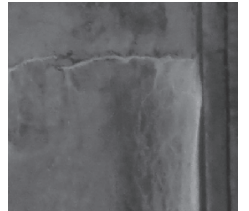

(b)

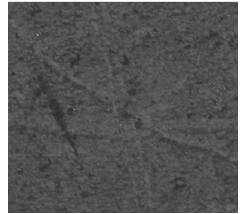

(d)

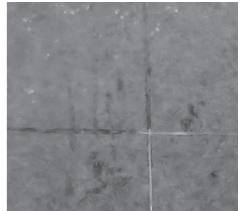

(c)

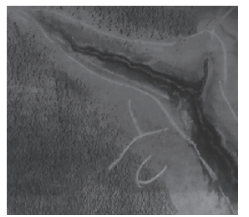

(e)
Fig. 1 Various discolored parts of tunnel inner wall. (a) Cracks in a clean wall, (b) lime deposited in a water leakage part, (c) dirt adhered to mold parting line, (d) particles contained in the exhaust gas have adhered, (e) cracks in typical discolored parts.
持ち, この方式によって実用化されたシステムも存在し ている。しかし得られる画像の分解能が高くないため, デジタルカメラを用いる方法と同様の問題点を持つ.

もう一つは市販のレーザースキャナーを車載し, 全 方位の距離測定を行うことで， $\mathrm{mm} \sim \mathrm{cm}$ 精度のトンネ ル概形を得る方法 (Mobile Mapping System: MMS)であ る ${ }^{15-17)}$ ，インフラ関連の研究でレーザーが利用される ケースの多くがこちらである。しかし，得られる3D形 状の分解能は低く，ひび割れのような詳細な凹凸を検出 することは難しい.

本稿では, 我々が開発している, レーザーを用いたト ンネル内壁表面のひび割れや劣化をこれまでにない高空 間分解能で計測するシステムについて報告する。我々 は，これまでに開発してきたレーザー技術をもとに，遠 隔的にトンネル内壁表面の状態を, 高効率かつ分解 能 $0.2 \mathrm{~mm}$ 以下の高精度で計測するためのイメージス キャナーの開発を進めてきた。その結果, レーザーの射 出点から 5 m離れたトンネルの壁面を計測対象として, 従来実現していなかった (1) 空間分解能の高い反射光イ メージング, (2) 周波数帰還形 (FSF) レーザーによる高 分解能距離計測, (3) 分光の手法に基づく漏水検出, 壁 面の污れと傷の識別が可能になった，屋外における計測 結果についても示す.

\section{2.レーザー計測システムおよび実験結果}

\section{1 高空間分解能ライダーの実現}

我々の目的は, 従来の2D画像情報では困難であった, ひび割れの高い信頼性での遠隔識別を達成することであ る. 我々の高分解能レーザー測定は, 従来の方法と異な り，トンネル壁の微細な凹凸を直接検出するのに十分な 分解能で距離測定を行う点が特徵である。実験システム をFig. 2 に示す。実験システムは, 光源としてのレー ザー発振器, 投受光の分離混合システム, 集光点を機械 的に3D走査するシステム，および同軸に受信された反 射光を分析するための検出ユニットからなる．複数の レーザー発振器と検出ユニットを切り替えることで, 共 通の伝送システムを用いて複数の測定を行うことができ る.

本研究の主な計測対象が5 $\mathrm{m}$ はなれた幅 $0.2 \mathrm{~mm}$ 以上の ひび割れであることから，コンクリート面内方向の高い 分解能が必須である，本研究では，集光スポットの小型 化とガルバノスキャナの高精度化により実現している。 集光スポットの小径化は, 光学理論の基本に従い, 出射 ビーム径を大きくとり，大きな開口と精密なレンズ系を

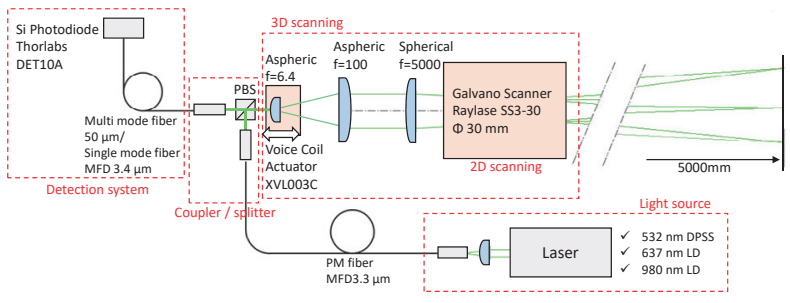

Fig. 2 Diagram of experimental setup. 
用いることによって回折限界に近い小さな集光スポット を達成する，小さな集光スポットを実現するため，レー ザー光をシングルモードファイバによりモード選択した 後, ビームスプリッタによってレンズ系の光軸に結合し た。ビームは焦点距離の制御機構を通過後, 焦点距 離100 mmの非球面レンズによってコリメートされ，焦 点距離5000 mmの集光レンズを使用して5 m離れたター ゲット上にほぼ回折限界で集光した。ガルバノスキャナ に関しては, 高速焦点制御機構と直径 $30 \mathrm{~mm}$ のガルバノ ミラーを用いて壁面の高速撮像を実現した.

集光性能の主な制約は，ガルバノミラーの面積であ り, 機械的な制約からビーム径が30-50 mm以下程度に 制限される。集束スポットの直径を決定する他の重要な 要素は, 光の波長である. 出射ビーム直径 $30 \mathrm{~mm}$ の光学 系が, ガウシアンビームを透過効率 $80 \%$ で伝達すると仮 定すると, 回折限界のスポットサイズは, 光の波長 が532 nmの場合 $165 \mu \mathrm{m}$, 波長が637 nmの場合で $198 \mu \mathrm{m}$ である。我々の試作したシステムでは，波長 $637 \mathrm{~nm}$ の 光源を用いた屋外試験において, 実測スポット径 $220 \mu \mathrm{m}$ が得られた。これは回折限界の $111 \% に$ 相当する。

Fig. 3 に， 5 m離れた位置で測定した集光スポットの CCD画像を示す. 高速な可変焦点機構のためにやや複 雑なレンズ系であるにもかかわらず，ほぼ回折限界のガ ウス分布が維持されているのが確認された。

我々はこのシステムを用いて3つの原理で測定を行い， コンクリート面からより多くの情報を引き出すことを目 指して開発を進めた。 以下に詳細を述べる。

\subsection{FSFレーザーによる距離測定}

軸方向の精密距離測定は, 本研究において最も重要で ある. 特に, 本研究で対象としているコンクリート壁の 粗面は研磨されていないため, 距離測定の結果には測定 に用いるレーザー光のスポット範囲に含まれる凹凸に起 因する誤差が含まれる。この誤差はスポット径が大きい ほど増加するため， スポット中心部における正確な距離 を測定するためには十分小さなスポットに焦点を絞った 光を用いて高い空間分解能を維持することが必要とな る.

我々は周波数シフト州還形(FSF) レーザー ${ }^{18,19)}$ を使用 した10-100 $\mu \mathrm{m}$ の高分解能 ${ }^{20)}$ で比較的高速に測定を行う ことができる距離測定システムを開発した。このレー ザーの特徵は，共振器に導入された周波数シフタによ り，発振波長が時間とともに直線的に連続的にシフトす

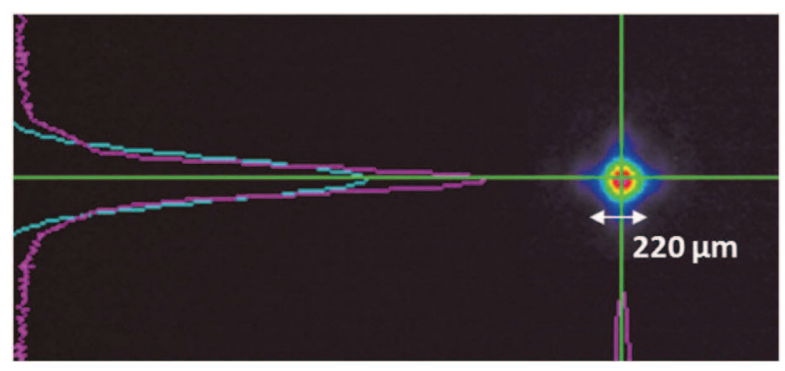

Fig. 3 Focal spot image of the $637 \mathrm{~nm}$ laser.
る点にある，発振器から放射された光が標的まで往復す る間，発振器によって放射される光の周波数は，経過時 間に対応する量だけシフトされる.Fig. 4 に示す通り に，光学干渉により周波数シフト量を自己へテロダイン 検出することで，経過時間を高精度に求めることがで き，ターゲットまでの往復距離を高精度に測定すること ができる.

この試作機は，距離を $1 \mathrm{kHz}$ の測定レートで取得で き，5 m離れた位置で使用したときの測定精度は標準偏 差0.1 mmである。この計測スピードは1秒あたり $6 \mathrm{~mm} \times$ $6 \mathrm{~mm}$ の面積に相当する。また，集光スポットは回折限 界には達していないが, 試作機は屋内環境におい

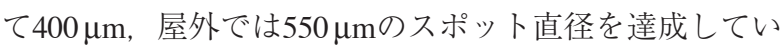
る.

切削によって正確に0.2 mm幅の細い溝を形成したコ ンクリート試料の表面測定結果をFig. 5 に示す. Fig. 5 (a)に示す通り, 試料はスポット径と同等の溝幅を有し ているが，正しく検出し，分解できたことを確認した． 測定距離の標準偏差は $100 \mu \mathrm{m}$ であったが, 偏差はほぼガ ウス分布に従っているため, 同じ点で繰り返し測定して 得られた值を平均することにより，より高い精度を得る ことができることが分かった。

コンクリート上のひび割れに対して3D測定を行った 結果をFig. 6 に示す. Fig. 5 の溝付きコンクリート試料 と同様に，スポット直径と同等の幅のひび割れを検出す ることに成功した。

このように3D情報からのひび割れ検出は, コンク リート上の反射強度のコントラストに依存せず，ひび割 れと健全部が同じ明るさに見える場合にも，高いひび割 れ判別能力が期待される。この特性は, 従来のカメラ画 像による測定が有効でない変色領域を測定するために非 常に有利であると期待される。

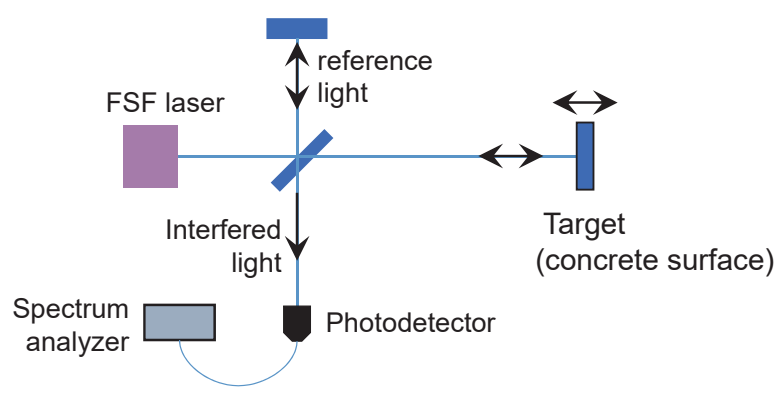

Fig. 4 FSF laser ranging.

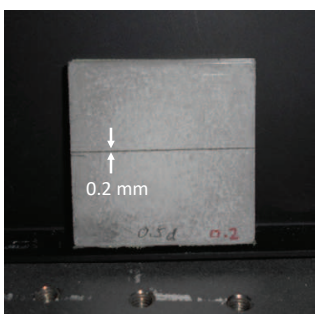

(a)

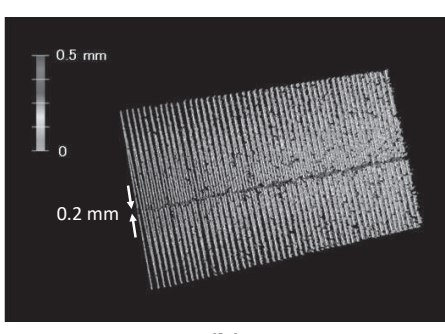

(b)
Fig. 5 Measurement results of grooved concrete specimens. 

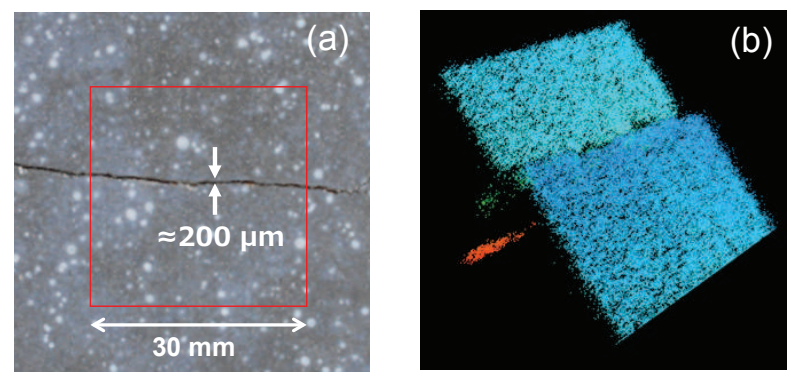

Fig. 6 Measurement results of a concrete crack. (a) Photographic image, (b) 3D measurement result with FSF laser.

\section{3 高分解能反射光イメージング}

高分解能ライダーをそのまま用い, スキャン座標と共 に記録した反射強度を2Dマップ化することで, レー ザースキャンされた反射光画像が得られる. 高速記録で きる点が特徴で, ガルバノスキャナの機械的速度限界ま で高速化ができる。1秒間に60 mm × $60 \mathrm{~mm}$ と, 距離測 定と比較して最大 100 倍の速度でのスキャンが実現でき ている.

$637 \mathrm{~nm}$ の光でコンクリート面のひび割れを測定した 結果をFig. 7 に示す. Fig. 7 (a)の近接撮影した写真画像 にある $0.2 \mathrm{~mm}$ と0.3 mm幅のひび割れがFig. 7(b)に示す反 射率画像でも確認できた. Fig. 7 (c) に示す断面の強度プ ロファイルにおける輝度分布においても明確に識別する ことができる. 近接写真Fig. 7(a)には0.15 mm幅のひび 割れも見られるが, これは5 m離れた位置からのレー ザー測定結果においては十分に鮮明ではない.

解像度をより定量的に確認するためISO-12233チャー トを用いた評価を行った. $637 \mathrm{~nm}$ の光を用い, $5 \mathrm{~m}$ 離れ て取得したイメージFig. 8(b)において, 9本の線が分解
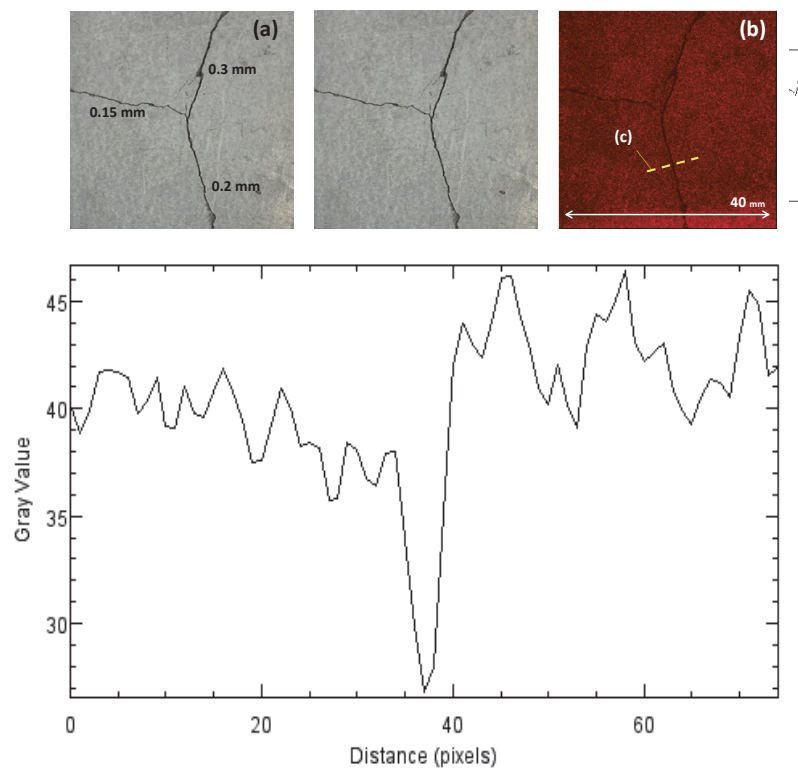

(c)

Fig. 7 Measurement results of laser reflection imaging. (a) Photo image of cracked concrete, (b) reflectance image obtained with $637 \mathrm{~nm}$ laser, (c) cross sectional shape of reflectance image.
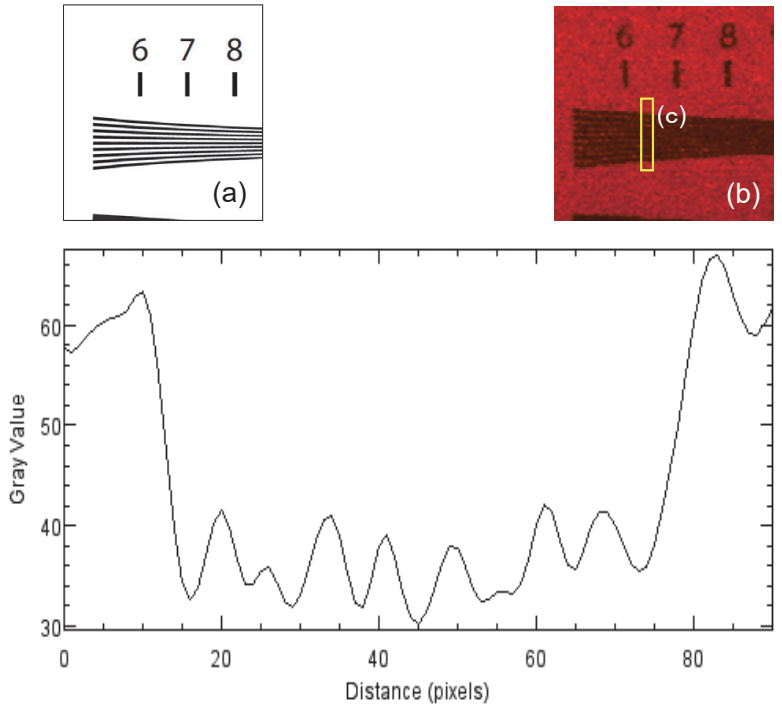

(c)

Fig. 8 Reflectance images of ISO-12233 chart. (a) A part of ISO-12233 chart, (b) reflectance image obtained with $637 \mathrm{~nm}$ laser, (c) cross sectional shape of reflectance image.

されている限界付近のプロファイルをFig. $8(\mathrm{c})$ に示す. この時のストライプ線幅は $0.14 \mathrm{~mm}$ あ゙る。同様 に980 nmの光を用いた場合幅 $0.25 \mathrm{~mm}$ のスライプパ ターンを解像できた。 以上から実験システムは，実測さ れたスポット直径に相当する解像度を有することを確認 できた。

2.4 レーザー分光

レーザー光は, 放出される光の時空間的集光密度の点 で優れた性能を有するばかりでなく，特定の波長に集中 したエネルギーを有する単色光であるという重要な特徴 も有する。 この特徵は, 光の波長を変化させながら材料 の応答を観察することにより分光測定を行う上で非常に 有利である。

我々のレーザービーム反射率測定システムは, 光源と して波長可変レーザーを組み合わせた場合，そのままで 反射分光を行うことができる，得られた分光情報を用い てコンクリート表面の変色や漏水領域を特定し, 亀裂の 検出精度向上が期待できる。漏水だけでなく，他の化学 的劣化を検査するための分光データを取得することも可 能である,

反射イメージングの実験システムを用いて，光源の波 長のみを変化させることで反射分光を行うことができ る。一例として，2波長差分吸収ライダー(DIAL)による 水の計測を行った例をFig. 9 に示す。液体の水による光

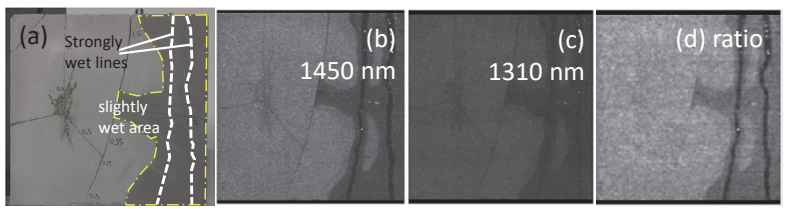

Fig. 9 DIAL measurement result of water. 


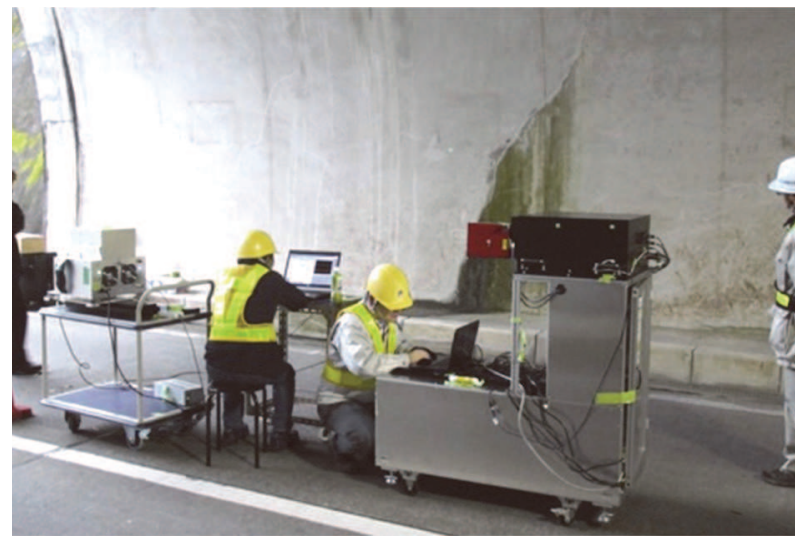

Fig. 10 Field test in Ogamo Tunnel, Shimoda.
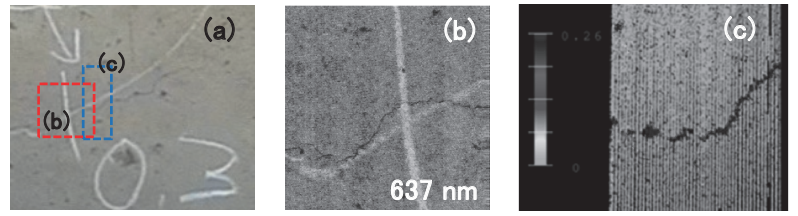

Fig. 11 Measurement results in Ogamo Tunnel. (a) Photographic image, (b) Reflection intensity measurement, (c) 3D measurement.

吸収ピーク に21) に近い1450 nm(b) と, off波長とし て1310 nm(c) を用いた2波長でイメージを取得し, 両者 の輝度の比を取ることで(d)のように漏水を模した水に よる吸収部のマップが得られる。これは可視光画像 (a) からは得られない情報の一例である。

\section{3. 外部フィールドにおける評価}

実験室での評価と並行して，2016年7月27～29日に静 岡県富士市の施工技術総合研究所, 2016年11月28日に静 岡県下田市大賀茂卜ンネル (Fig. 10)においてそれぞれ屋 外トンネルで各システムの評価を行った。

フィールド実験の主な目的は，実験的に製造されたデ バイスが様々な環境下で正常に動作するかどうかを判断

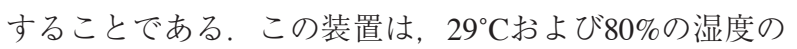
環境下で実験室と同様に動作することを確認した。トン ネル内に自然に発生したひび割れの反射強度測定結果 Fig. 11 では，近接撮影写真Fig. 11 (a)に見られる0.3 mm 幅のひび割れの細部が, $637 \mathrm{~nm}$ 光による反射強度測定 の結果Fig. 11 (b) と, FSFレーザーによる距離測定結果 Fig. 11 (c) に捉えられている. Fig. 11 (c) に示すように, ビーム径 $550 \mu \mathrm{m} よ り$ 小い $0.3 \mathrm{~mm}$ 幅の亀裂が凹状の線 として検出された。 これは屋外においてもひび割れの色 調によらない3D計測が有効に働くことを示している。

\section{4. まとめと今後の展望}

本稿では, 現在開発を進めているレーザーを用いた高 精度な遠隔計測システムについて述べた。本システムは，
FSFレーザーを用いたひび割れ形状の検出，反射率イメー ジング手法の二つからなり，遠隔計測で必要となる $5 \mathrm{~m}$ は なれた位置から0.2 mmのひび割れを検出できることを実 証した。特に，反射イメージングシステムについては，共 通の光学系で分光イメージングシステムとして利用でき る.これは, 漏水や塩分など異物を検出できる可能性を 示しており，高度なトンネル壁面検査が期待できる。

現在，実トンネルでの利用に向けて，屋外環境におけ る実験を行いつつシステムの社会実装に取り組んでい る。これらの取り組みを通して，機械検査による定量的 な点検が実現し，トンネルの維持管理業務の効率化に貢 献したいと考えている.

\section{謝 辞}

本研究は, 内閣府総合科学技術・イノベーション会議 の「SIPインフラ維持管理・更新・マネジメント技術」(管 理法人：JST）によって実施された.

\section{参考文献}

1) Y. Matsuda: Japan Railway and Transport Review 62 (2013) 32.

2) P. C. Chang, A. Flatau, and S. C. Liu: Structural Health Monitoring 2 (2003) 257.

3) C. Koch, K. Georgieva, V. Kasireddy, B. Akinci, and P. Fieguth: Advanced Engineering Informatics 29 (2015) 196.

4) F. C. Sham, N. Chen, and L. Long: Insight 50 (2008) 240.

5) H. C. Rhim and O. Buyukozturk: J. Structural Eng.126 (2000) 1451.

6) A. Taketani, Y. Seki, H. Ohta, T. Hashiguchi, S. Yanagimachi, Y. Otake, Y. Yamagata, Y.Ikeda, H. Baba, S. Wang, et al.: Proceedings of IPAC (2015) 2262.

7) Y. Shimada and O. Kotyaev: IEEJ Trans. Electron. Information and Systems 129 (2009) 1192.

8) W. Zhang, Z. Zhang, D. Qi, and Y. Liu: Sensors 201414 (2014) 19307.

9）鵜飼 正人, 下田一也：建設の施工企画 741 (2011) 35.

10) I. A. Qader, O. Abudayyeh, and M. E. Kelly: J. Computing in Civil Eng. 17 (2003) 255.

11) S. Yokoyama and T. Matsumoto: Procedia Eng. 171 (2017) 1250

12）佐野信夫, 伊藤哲男, 馬場弘二, 西村和夫, 吉武勇, 中川 浩二：土木学会論文集F 62（2006） 558 .

13）半田 兼一, 大西有三, 西山哲, 小山倫史, 西川啓一, 下澤 正道: 第38回岩盤力学に関するシンポジウム講演集 (2009) 184.

14）奥野昇, 嶋津 幸一, 伊藤哲男, 馬場 弘二, 吉武勇, 中川 浩二：土木学会論文集 788 (2005) 195.

15) W. Wang, W. Zhao, L. Huang, V. Vimarlund, and Z. Wang: J. Traffic and Transportation Engineering 1 (2014) 325.

16) E. Protopapadakis, C. Stentoumis, N. Doulamis, A. Doulamis, K. Loupos, K. Makantasis, G. Kopsiaftis, and A. Amditis: ISPRS Annals of the Photogrammetry, Remote Sensing and Spatial Information Sciences 3 (2016) 167.

17) K. Ishikawa, J. Takiguchi, Y. Amano, T. Hashizume, and T. Fujishima: JRM 21 (2009) 193

18) S. Wada, K. Akagawa, and H. Tashiro: Opt. Lett. 21 (1996) 731.

19) J. Geng, S. Wada, N. Saito, and H. Tashiro: Opt. Lett. 24 (1999) 1635.

20) H. Ito, T. Hara, and C. Ndiaye: Re. Laser Eng. Supplemental Volume (2008) 1038.

21) G. M. Hale and M. R. Querry: App. Opt. 12 (1973) 555. 